\section{An automated method for the quantitative assessment of low concentrations of glucose in urine}

A. M. EMMERSON, P. GARCIA-WEBB ${ }^{1}$ AND SUSAN J. TURNER From the Departments of Bacteriology and Clinical Biochemistry, University College Hospital, London

In view of the recent work by Schersten and Fritz (1967), which indicates that the utilization of small amounts of glucose in urine by actively respiring bacteria can be used as an index of urinary tract infection, there is a need for a simple, sensitive test which detects very low concentration of urine glucose and can be applied in the analysis of large numbers of specimens.

This paper describes the adaptation of a routine blood glucose autoanalyser method to the measurement of glucose in urine.

\section{Method}

\section{URINE SAMPLES}

Substances which interfere with the measurement of glucose in urine by the glucose oxidase method were removed by the following technique:

Five $\mathrm{ml}$ of uncentrifuged, well mixed urine was added to a capped $10 \mathrm{ml}$ polythene tube containing approximately $1.5 \mathrm{~g}$ of dry Amberlite resin IR 400 $(\mathrm{Cl}-)^{2}$ and $1.5 \mathrm{~g}$ of dry Amberlite resin IR $45(\mathrm{OH}-)^{2}$. The contents were mixed by inversion until a uniform distribution of the resins was obtained. The tube was then left for one hour and inverted once before centrifuging at $3000 \mathrm{rpm}$ for five minutes. The supernatant was then transferred to autoanalyser cups. The standards were treated in an identical manner to the urine samples. The upper limit for accurate measurement without dilution was $20 \mathrm{mg}$ / $100 \mathrm{ml}$.

The method of estimation used was the micro glucose method described by Trinder (1969), in which 4 amino-phenazone acts as the electron acceptor and is incorporated into the diluent while the colour reagent contains glucose oxidase, peroxidase, and phenol. The following modifications were made. The sampling rate was $40 /$ hour with a sample:

\footnotetext{
'Present address: Alfred Hospital, Melbourne, Australia.

2Supplied by British Drug Houses.
}

Received for publication 5 January 1973. wash ratio of $1: 2$. The sample was not diluted. A range expander was incorporated in the recorder which approximately doubled the peak height size. A $10 \mathrm{~mm}$ flow cell was used.

\section{STANDARDS}

The standards, which were made up in $0.2 \mathrm{~g} / 100 \mathrm{ml} \stackrel{\mathbb{\complement}}{\varrho}$ benzoic acid (AR, BDH), contained glucose at $\%$ concentrations of $1,2,3,5,10$, and $20 \mathrm{mg} / 100 \mathrm{ml}$. The $2 \mathrm{mg} / 100 \mathrm{ml}$ standard was used for drift correction, being placed in two cups after each subsequent group of eight unknown specimens. A calibration curve was drawn from the standard peaks using a Technicon chart reader; a drift line was drawn through the second of each pair of drift standards os and the values of the unknown read off in the normal is way. The values were read to the nearest $0.1 \mathrm{mg} / 100$ $\mathrm{ml}$.

VALIDATION OF URINE GLUCOSE METHOD Exposure of the urine to the resins for varying periods up to two hours showed that exposure for less than $\vec{\theta}$ 30 minutes gave recoveries of less than $100 \%$ but that after 30 minutes no significant improvement occurred in the recovery. One hour was therefore used to standardize the procedure and under these conditions the mean percentage recovery of glucose added to urine to give concentrations of glucose between 3.3 and $23.3 \mathrm{mg} / 100 \mathrm{ml}$ was $99.9 \%$ (range 97-102\%).

In order to check for possible interference, four glucose solutions of $10 \mathrm{mg} / 100 \mathrm{ml}$ were prepared containing creatinine $250 \mathrm{mg} / 100 \mathrm{ml}$, urea $4 \mathrm{~g} / 100$ $\mathrm{ml}$, sodium chloride $0.9 \mathrm{~g} / 100 \mathrm{ml}$, and uric acid 100 $\mathrm{mg} / 100 \mathrm{ml}$ respectively. No interference was detected with the glucose estimation following treatment with the resins.

Urine ascorbic acid (Harris and Ray, 1935) and urine glucose concentrations were also estimated on an early morning urine specimen from one of us (S.J.T.) after taking $1200 \mathrm{ml}$ of orange juice containing at least $250 \mathrm{mg}$ of ascorbic acid late the previous evening. The mean recovery of glucose $N$ added to the urine which contained $10 \mathrm{mg} / 100 \mathrm{ml} \mathrm{N}$ of ascorbic acid (collected from S.J.T.) was $99 \%$.

\section{Comment}

A mixture of a weak and a strong anion exchange $\overparen{\unrhd}$ resin which has been used substantially increases the urinary glucose recovery compared with the mixture of anion and cation exchange resins described by Tengstrom (1966). This effective combination was found after many experiments some of which were purely empirical. Ascorbic acid is not removed by these resins and remains as a possible source of $\varnothing$ 
error. Sutherland, Stowers, and McKenzie (1970) found the range of concentration of ascorbic acid in urine obtained from patients attending antenatal clinics was $1 \cdot 0-2.3 \mathrm{mg} / 100 \mathrm{ml}$ with a mean of 1.6 $\mathrm{mg} / 100 \mathrm{ml}$. The method described here shows normal recovery of glucose in the presence of $10 \mathrm{mg} / 100 \mathrm{ml}$ of ascorbic acid. Interference by ascorbic acid in this method is therefore not likely to be significant unless the patient has been taking large doses of vitamin $\mathrm{C}$ daily.

In order to check the precision of the method 24 estimations were performed on urines with a mean glucose concentration of $3.32 \mathrm{mg} / 100 \mathrm{ml}$ and gave an SD $=0.12$ and a coefficient of variation of $3.59 \%$, and 20 estimations were made on urines with a mean glucose concentration of $6.51 \mathrm{mg} / 100 \mathrm{ml}$ which gave an SD $=0.18$ and coefficient of variation of $2.7 \%$.

The automated method described in this paper has been performed on 500 specimens of early morning urine in parallel with the simple Uriglox ${ }^{1}$ paper strip test. The results obtained confirmed the claims of the manufacturers that a positive Uriglox test is indicative of an urinary glucose concentration of less than $2 \mathrm{mg} / 100 \mathrm{ml}$.

\section{References}

Emmerson, A. M. (1972). The use of a simple test for hypoglucosuria (Uriglox) in the diagnosis of bacteriuria in pregnancy. J. Obstet. Gynaec. Brit. Commonwealth, 79, 828-832.

Harris, L. J., and Ray, S. N. (1935). Diagnosis of vitamin C subnutrition by urine analysis. Lancet, 1, 71-77.

Scherstén, B., and Fritz, H. (1967). Subnormal levels of glucose in urine: a sign of urinary tract infection. J. Amer. med. Ass., 201, 949-952.

Sutherland, H. W., Stowers, J. M., and McKenzie, C. (1970). Simplifying the clinical problem of glycosuria in pregnancy. Lancet, 1 , 1069-1071.

Tengström, B. (1966). Enzymatic determination of glucose and galactose in urine. Scand. J. clin. lab. Invest., 18, Suppl. 92, 104-113.

Trinder, P. (1969). Determination of glucose in blood using glucose oxidase with an alternative oxygen acceptor. Ann. clin. Biochem., 6, 24-27.

Supplied by William R. Warner and Co Ltd, Eastleigh, Hampshire.

\section{An apparatus for the thawing of stored blood in liquid nitrogen}

\author{
R. MITCHELL, W. MUIR, AND E. A. MCLAREN From \\ the Glasgow and West of Scotland Regional Blood \\ Transfusion Centre, Law Hospital, Carluke, \\ Lanarkshire, Scotland
}

Thawing of glycerolized donations of frozen blood from liquid nitrogen storage requires some form of rapid agitation of the container in a large volume of water at around $40^{\circ} \mathrm{C}$ (Hurn, 1968). This can be achieved by a variety of modified water baths. We wish to report our experiences using a modified (second hand) domestic washing machine for this purpose. Models with centre spindle agitators and a means of thermostatically maintaining the temperature of a pre-heated water load are best, such as the Hotpoint Empress (fig 1). The central agitator spindle is tapped to take a standard screw, holding an angled strip of heavy gauge aluminium. To this is attached a wooden frame with four equidistant riccles removed to take the aluminium canisters Received for publication 22 February 1973.

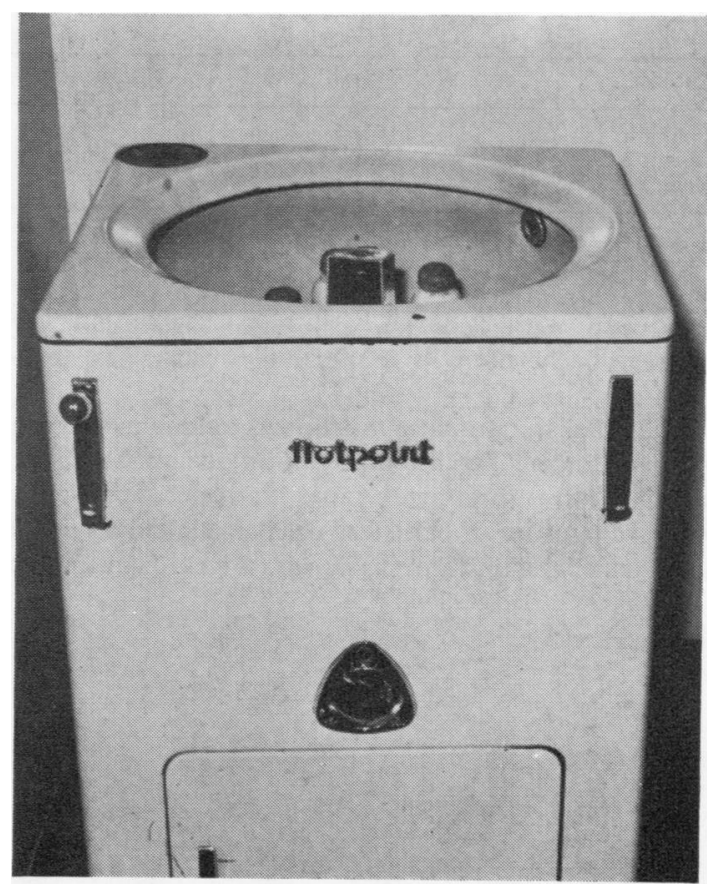

Fig 1 Main thawing unit. 